\title{
Seed-Production Potential of Tephrosia vogelii in Puerto Rico ${ }^{1}$
}

\author{
D. K. Barnes and R. H. Freyre ${ }^{2}$ \\ INTRODUCTION
}

The legume, Tephrosia vogelii Hook $f$., is a promising source of the natural insecticide, rotenone. It has been considered as a crop appropriate for southern United States and Puerto Rico (2). ${ }^{3}$ The environmental conditions required to induce flowering and seed production have made it necessary to conduct all breeding and genetic studies in Puerto Rico. For the same reasons it is anticipated that all future seed production of $T$. vogelii must be grown either in Puerto Rico or Central America.

According to Barnes, ${ }^{4} T$. vogelii is a self-pollinated species, but it usually requires an insect pollinator to trip the flowers so that self-pollination can take place. The primary pollinator in Puerto Rico is the carpenter bee (Xylocopa brasilianorum L.).

Two experiments were undertaken in 1963 and 1964: 1, To evaluate the seed-production potential of several $T$. vogelii breeding lines; 2 , to explore the possibilities of selecting within breeding lines for high seed-producing plants; and 3, to study possible interrelationships among days to flower, plant height, percentage total rotenoids, and seed-production potential.

\section{MATERIALS AND METHODS}

On April 23, 1963, six high-rotenoid breeding lines were established in a seed-increase nursery at the Isabela Substation of the Agricultural Experiment Station of the University of Puerto Rico. The nursery was designed as a $6 \times 6$ Latin square. Each plot consisted of one 8-plant row. The plant spacing was approximately $1 \mathrm{~m}$. within rows and $1.3 \mathrm{~m}$. between rows. The nursery was seeded at a rate of four seeds per hill, and later thinned to one plant per hill. Seeds were scarified and inoculated with rhizobium prior to planting. Days from planting to first flower and seed yield were recorded for each individual plant.

On May 13, 1964, 24 entries were seeded in a new seed-increase nursery at the Isabela Substation. The 24 entries represented 4 of the breeding lines

1 Contribution from Crops Research Division, Agricultural Research Service, U.S. Department of Agriculture, Federal Experiment Station, Mayagüez, P.R. 00708.

2 Research Geneticist, Department of Agronomy and Plant Genetics, University of Minnesota, St. Paul, Minnesota 55101, (formerly Mayagüez, P.R.), and Research Agronomist, Mayagüez, P.R., respectively.

${ }^{3}$ Italic numbers in parentheses refer to Literature Cited, p. 212.

- Unpublished data. 
from the 1963 planting and 19 new lines established from high seed-yielding plants in the 1963 planting. Entry 10247 was included because it represented one of the best seed-producing lines available in the breeding program. The nursery was designed as a randomized block design with five replications. Each plot consisted of one 6-m. row. Fifty seeds were planted per row and when the plants were established, they were thinned to leave a maximum of 14 plants per row. Days from planting to first flower, plant height in inches, percentage total rotenoids, seed per row, and plants per row, were recorded. Total rotenoid determinations were made according to the red-color test described by Barnes and Freyre (1).

Data from both the 1963 and 1964 studies were statistically analyzed by the analysis of variance, and entry means ranked according to the Duncan's Multiple Range Test. Seed-yield per plot in the 1964 test was adjusted by a covariance analysis according to differences in plant number per plot.

TABLE 1.-Average days to first flower and seed yield per plant for 6 lines of Tephrosia vogelii in 1968 planting (Isabela, P.R.)

\begin{tabular}{c|c|c}
\hline Breeding line & Days from planting to first flowers & Average seed yield per plant (g.) \\
\hline 6273 & $164 \mathrm{a}$ & $1.7 \mathrm{ab}$ \\
6285 & $192 \mathrm{c}$ & $5.3 \mathrm{abc}$ \\
6286 & $192 \mathrm{c}$ & $8.9 \mathrm{c}$ \\
62121 & $187 \mathrm{bc}$ & $5.8 \mathrm{bc}$ \\
62159 & $182 \mathrm{~b}$ & $1.1 \mathrm{a}$ \\
62161 & $181 \mathrm{~b}$ & $1.1 \mathrm{a}$ \\
\hline
\end{tabular}

1 Means followed by same letter are alike at 5-percent level of probability accord ing to Duncan's Multiple Range Test.

\section{EXPERIMENTAL RESULTS}

In the 1963 planting the six breeding lines varied significantly in average date of first flower and seed yield per plant (table 1). Within-line variation for both maturity and seed-yield, as well as between-line variation was observed. Most of the plants produced abundant flowers but the percentage of pod set was very low. Nearly 33 percent of the plants in line 6273, and approximately 5 to 10 percent of the plants in the other five lines failed to set any pods. Very few carpenter bees were seen working the flowers. Therefore, much of the low pod-set was attributed to lack of pollinating insects.

The low seed-set of all lines caused some concern regarding the seed production potential of $T$. vogelii, especially when it was considered that the highest seed-producing line (6286) would have produced only $70 \mathrm{~kg}$. of seed per hectare. Nevertheless, many individual plants, especially in lines 6285, 6286 and 62121 , produced relatively good seed yields. The extremely wide spacing distances between plants also contributed to the very low production per hectare. 
TABLE 2.-Average seed yield, malurily, plant height, and rolenoid content for $5 \mathbf{T}$. vogelii breeding lines, and 19 lines previously selecled for high seed yields.

(Isabela, P.R., 1964) 1

\begin{tabular}{|c|c|c|c|c|c|}
\hline & Entry & $\begin{array}{c}\text { Average seed² per } \\
\text { plant }\end{array}$ & Days to first flower & Plant height & $\begin{array}{l}\text { Total rotenoids in } \\
\text { leaf }\end{array}$ \\
\hline & & Groms & Number & Inches & Percent \\
\hline 6273 & (original) & $10.9 \mathrm{de}$ & $156.0 \mathrm{e}$ & $60.4 a-c$ & $3.11 \mathrm{a}$ \\
\hline & $(3-2)$ & $8.1 \mathrm{e}$ & $175.4 \mathrm{a}-\mathrm{c}$ & 52.6 de & $2.96 a b$ \\
\hline & $(23-2)$ & $13.2 \mathrm{c}-\mathrm{e}$ & $169.0 \mathrm{~cd}$ & $63.8 \mathrm{a}$ & $2.74 b-e$ \\
\hline & $(31-6)$ & 20.6 a-e & $168.4 \mathrm{~cd}$ & $59.6 \mathrm{a}-\mathrm{d}$ & $2.77 \mathrm{bc}$ \\
\hline 6285 & (original) & 20.7 a-e & $181.8 \mathrm{ab}$ & $61.8 \mathrm{ab}$ & $2.55 \mathrm{c}-\mathrm{f}$ \\
\hline & $(32-4)$ & $17.5 \mathrm{~b}-\mathrm{e}$ & $181 .(i \mathrm{ab}$ & $58.0 \mathrm{a}-\mathrm{d}$ & $2.48 \mathrm{~d}-\mathrm{f}$ \\
\hline & $(32-7)$ & $25.3 a-d$ & $175.4 \mathrm{a}-\mathrm{c}$ & $62.4 \mathrm{ab}$ & $2.63 c-f$ \\
\hline & $(32-8)$ & $20.0 \mathrm{a}-\mathrm{e}$ & 178.6 a-c & $58.6 \mathrm{a}-\mathrm{d}$ & $2.52 \mathrm{c}-\mathrm{f}$ \\
\hline 6286 & (original) & $19.8 \mathrm{a}-\mathrm{e}$ & $181.2 \mathrm{ab}$ & $5+.0 \mathrm{c}-\mathrm{e}$ & $2.54 \mathrm{c}-\mathrm{f}$ \\
\hline & $(11-3)$ & $24.8 \mathrm{a}-\mathrm{d}$ & $179.2 \mathrm{a}-\mathrm{c}$ & $59.4 a-d$ & $2.43 \mathrm{f}$ \\
\hline & $(11-5)$ & $21.3 \mathrm{a}-\mathrm{e}$ & $182.0 \mathrm{ab}$ & $59.2 \mathrm{a}-\mathrm{d}$ & $2.57 \mathrm{c}-\mathrm{f}$ \\
\hline & $(16-3)$ & $24.3 \mathrm{a}-\mathrm{d}$ & $182.2 \mathrm{ab}$ & (i1.6 ab & $2.55 \mathrm{c}-\mathrm{f}$ \\
\hline & $(22-2)$ & $26.8 \mathrm{a}-\mathrm{c}$ & $179.2 \mathrm{a}-\mathrm{c}$ & $58.4 \mathrm{a}-\mathrm{d}$ & 2.46 ef \\
\hline & $(23-6)$ & $19.6 \mathrm{a}-\mathrm{e}$ & $183.8 \mathrm{a}$ & $56.0 \mathrm{~b}-\mathrm{d}$ & 2.46 ef \\
\hline & $(29-5)$ & $25.5 \mathrm{a}-\mathrm{d}$ & $180.0 \mathrm{ab}$ & $60.6 \mathrm{a}-\mathrm{c}$ & $2.56 \mathrm{c}-\mathrm{f}$ \\
\hline & $(36 i-2)$ & $29.9 \mathrm{ab}$ & 177.6 a-c & $57.0 \mathrm{a}-\mathrm{d}$ & $2.53 \mathrm{c}-\mathrm{f}$ \\
\hline & $(36-4)$ & 33.6 a & $177.8 \mathrm{a}-\mathrm{c}$ & $59.4 a-d$ & $2.66 \mathrm{c}-\mathrm{f}$ \\
\hline & $(36-6)$ & $22.0 \mathrm{a}-\mathrm{e}$ & $181.6 \mathrm{ab}$ & $58.8 \mathrm{a}-\mathrm{d}$ & $2.55 \mathrm{c}-\mathrm{f}$ \\
\hline 62121 & (original) & $25.8 a-d$ & $173.6 a-c$ & $59.8 \mathrm{a}-\mathrm{d}$ & $2.63 c-f$ \\
\hline & $(7-1)$ & $23.7 a-d$ & $177.4 \mathrm{n}-\mathrm{c}$ & $62.2 \mathrm{ab}$ & $2.49 \mathrm{~d}-\mathrm{f}$ \\
\hline & $(21-2)$ & $29.5 \mathrm{ab}$ & $175.0 \mathrm{n}-\mathrm{c}$ & $55.8 \mathrm{~b}-\mathrm{d}$ & $2.74 b-d$ \\
\hline & $(35-3)$ & $26.6 \mathrm{a}-\mathrm{c}$ & $173.6 \mathrm{a}-\mathrm{c}$ & $58.6 \mathrm{a}-\mathrm{d}$ & $2.59 \mathrm{c}-\mathrm{f}$ \\
\hline & $(35-4)$ & $24.1 \mathrm{a}-\mathrm{d}$ & $172.0 \mathrm{bc}$ & $56.8 \mathrm{a}-\mathrm{d}$ & $2.73 \mathrm{~b}-\mathrm{e}$ \\
\hline 10247 & & $18.9 \mathrm{n}-\mathrm{e}$ & 159.4 de & $49.2 \mathrm{e}$ & $1.84 \mathrm{~g}$ \\
\hline $\mathrm{CV}(\mathrm{p}$ & jercent) & 46.1 & 4.3 & 8.1 & 6.9 \\
\hline
\end{tabular}

1 Means followed by same letter are alike at 5-percent level of probability according to Duncan's Multiple Range Test.

2 Mean seed yield per plant adjusted by covariance analysis for differences in st and.

In the 1964 planting the entries varied significantly for seed-yield, maturity, plant height, and rotenoid content (table 2). The four breeding lines that were grown in both the 1963 and 1964 plantings showed similar rankings for both seed yield and maturity ratings. Even though the progeny from some high-yielding plants in the 1963 planting were numerically greater than for the original lines, in no instance were the differences significant for seed-yield. In rotenoid content, maturity, and plant height, sev- 
eral of the progeny lines from 6273 were significantly different from the rotenoid content of the original line 6273 . The seed-yield for the better yielding lines was approximately 4:50-500 kg./ha., but this was far below the crop's potential. Usually only about 25 percent of florets produced pods (figure 1). Seldom did a raceme produce its full potential (figure 2).

Correlation coefficients using individual plot means were calculated in order to determine whether interrelationships existed among days-toflower, plant height, percent-rotenoids, and seed-yield. A low but significant



Fig. 1.-Typical low frequency of pod set on T. vogelii lines in 1964 seed-increase nursery, Isabela, P.l.

correlation coefficient of $r=-0.201^{*}, 118$ df indicated that earlier flowering lines tended to produce higher seed yields than later flowering lines. Tall plants also tended to produce higher seed-yields than short plants $\left(r=.199^{*}, 118 \mathrm{df}\right)$. No relationship was indicated between seed-yield and rotenoid content $(r=.067,118 \mathrm{df})$.

\section{DISCUSSION}

It was apparent in both the 1963 and 1964 field studies that the seedyield potential of $T$. vogelii was several times greater than that recorded. 
The lack of a significant relationship between rotenoid content and seedvield indicates that it should be possible to simultaneously breed for high rotenoid content and high seed-yield. The relatively low seed-yields of progenies from selected plants indicated that most of the within-line variation observed in the 1963 planting was caused by environmental rather than genetic factors. The homozygosity or lack of genetic diversity within lines for seed-yield, plant height, and maturity is typical of what would be expected in the advanced generations of a self-pollinated crop. Since within-

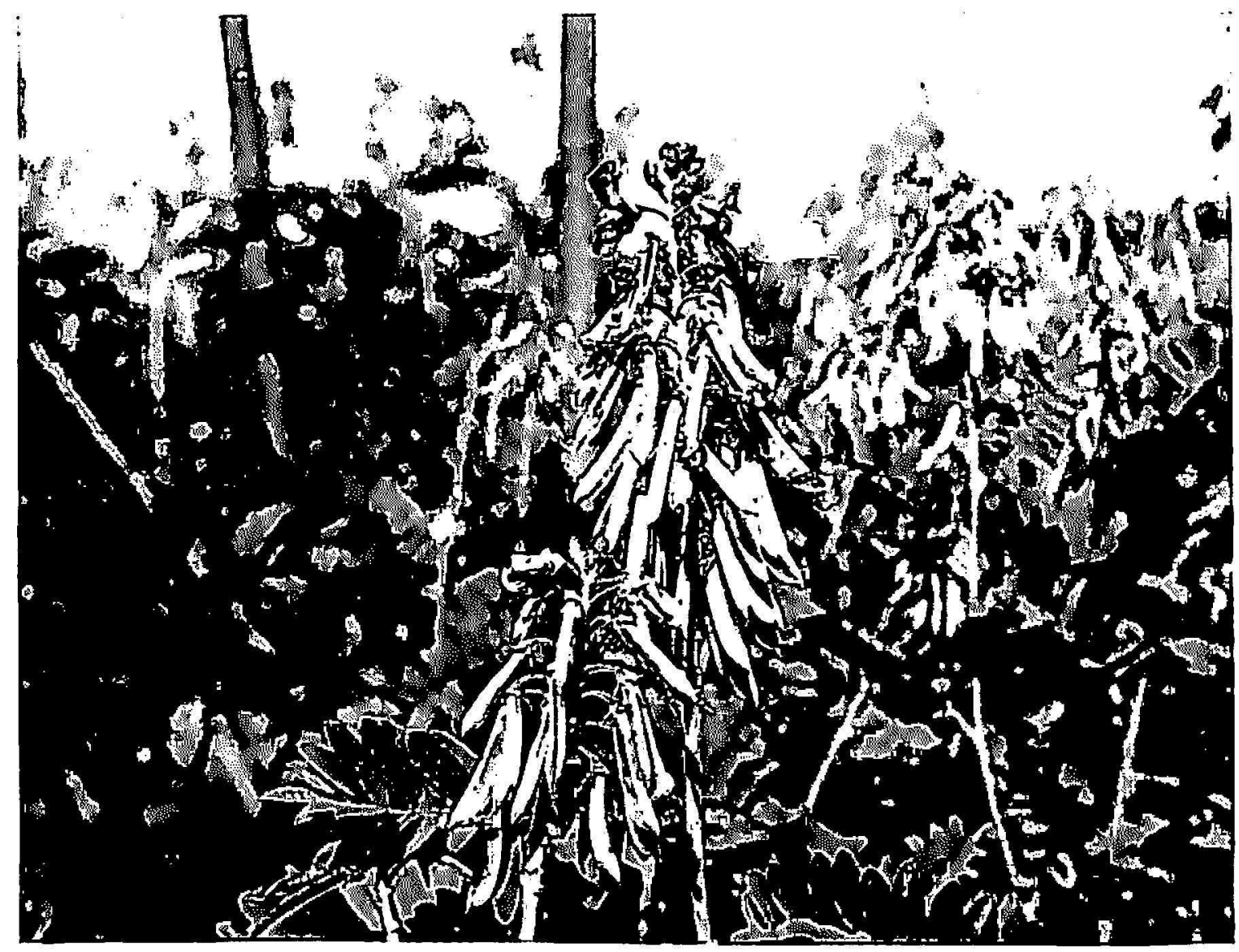

Fifi. 2.- Raceme of $T$. vogelii showing pod set potential of species.

line selection appears fruitless in T. vogelii, the most appropriate breeding approach would be to hybridize all of the best available seed-producing lines and the highest rotenoid-producing lines; then st udy either $\mathrm{F}_{2}$ plants or $\mathrm{F}_{3}$ lines for both high seed-yield potential and high rotenoid content.

If $T$. vogelii is to become an established crop for Puerto Rico and the southern C'nited States, its seed costs must be low and seed supplies dependable. Therefore, it is imperative that studies be initiated to ascertain the important envirommental, physiological, and genetic factors that influence pod-set and seed-set. Information obt ained from these studies would 
be useful in programs for breeding increased seed production and also in seed-multiplication programs.

\section{SUMMARY}

$T$. vogelii seed-production studies were established at the Isabela Substation of the Agricultural Experiment Station of the University of Puerto Rico in 1963 and 1964. Average seed-yields of the best producing lines ranged from approximately $450-500 \mathrm{~kg}$./hectare, but this was only a fraction of the crop's potential production. A large percentage of florets failed to set pods. This was partly attributed to lack of insect pollinators, but unknown environmental and physiological factors were also thought to be important.

Small but significant correlation coefficients indicated that the best seedproducing plants tended to be tall and to flower carly. No significant relationship was observed between rotenoid content and seed-yield. A breeding program that simultaneously selects for both seed-yield and rotenoid content is suggested.

\section{RESUMEN}

Durante los años 1963 y 1964, en la Subestación de Isabela de la Estación Experimental Agrícola de la Universidad de Puerto Rico se llevaron a cabo unos estudios para determinar la producción de semilla de la planta leguminosa Tephrosia vogelii. Las mejores líneas produjeron de 450 a $500 \mathrm{~kg}$. de semilla por hectárea, pero esto fue sólo una fracción de su capacidad de rendimiento. Un gran porcentaje de las flores no produjeron vainas. Esto se atribuyó, en parte, a la ausencia de los insectos polinizadores, pero también pudo haber sido ocasionado por factores ambientales y fisiológicos desconocidos.

Los coeficientes de correlación fueron pequeños, pero significativos, e indicaron la tendencia de que las mejores productoras de semillas fueran las plantas de mayor altura y también las que florecieron más temprano. No hubo relación significativa alguna entre el contenido de rotenoides y la producción de semilla. Se sugiere establecer un programa de hibridación para aumentar simultáneamente el rendimiento de semilla y el contenido de rotenoides.

\section{LITERATURE CITED}

1. Barnes, D. K., and Freyre, R. H., Recovery of natural insecticides from Tephrosia vogelii: III, An improved procedure for sampling and assaying rotenoid content in leaves, Econ. Bot. 21: 93-8, 1967.

2. Barnes, J. K., Freyre, R. H., Higgins, J. J., and Martin, J. A., Rotenoid content and growth characteristics of Tephrosia vogelii as affected by latitude and within-row spacing, ('rop Sci. 7: 93-5, 1367. 